\title{
THE INFLUENCE OF MANAUARA'S MUSIC ON THE CULTURAL IDENTITY OF RESIDENTS: A study on the Musical Event Tacacá na Bossa
}

\author{
Leonardo Vanderson Pereira Gama \\ Maria Adriana S.B. Teixeirab
}

\begin{abstract}
Nowadays it is known that music influences the destination choice because it is linked to the intangible heritage which strengthens the identity of a place. Therefore, it is known that the local music genres are very representative to establish a relationship between tourists and natives. Therefore, the overall goal is to analyze the influence of Manauara music on cultural identity through the Tacacá na Bossa event held in Largo São Sebastião. The specific goals are: Identify the Manauara music historicity and the Tacacá na Bossa event, researching the main characteristics of Manauara music through local artists and bands, and analyzing the importance of the musical event Tacacá na Bossa for residents with a form of cultural identity. It is believed that this study is necessary because music is present in different kinds of sociability. Regarding the Amazonian Popular Music - MPA is important in the local identity appreciation and discusses the customs and language among others. In the methodological aspect, the approach is qualitative and quantitative and the methodological objectives are descriptive and exploratory. The results allowed us to understand the Amazonian musicians goals, the importance of the local language to strengthen the culture and representativeness of the Tacacá na Bossa event for composers and visitors.
\end{abstract}

\section{Keywords:}

Music

Cultural Identity

Tacacá na Bossa 


\section{INTRODUCTION}

All around the world there will always be some music that will serve as a reminder of that particular place, whether through its own sound or even through musical shows, music is the population's cultural identity. Nowadays, music has influenced tourist destination choices, such as the music experience in the destination itself, or even experiencing the music that is the identity of the destination in some event during the trip.

It is known that when traveling we are looking for knowing the location heritage, which inserts the intangible heritage that remains in our memory and represents the identity of that place. According to Costa and Castro (2008) in order for heritage to represent the place's identity, it must be elected, and given value, which takes place in the context of social and symbolic reactions that are made around the object or event itself.

The authors explain that myths, legends, tales, songs are fragments that occur between memory and experience of groups, are records of lived experiences, and symbolize the immaterial heritage. Collective memories are materialized through these symbols that when externalized through orality or writing, act as a socialization operator in the collective activities developed by the group.

The world has become globalized, people are constantly seeking to know new cultures and ways of thinking, which could include the musical process, as they appreciate musical development and be rocked by the rhythms that can perpetuate culture in its local and national context, as in this globalized process, certain instruments become obsolete in a short period of time (Pereira, 2014)

Through the words of the author mentioned above, we can associate some musical genres to Brazilian regions, such as: Samba that started as maxixada and becomes what we know today started in Rio de Janeiro; Chorinho also started in Rio de Janeiro in 1930; The Brazilian Popular Music - MPB began at the festivals in the Southeast; National rock that originated in the South, Southeast and Midwest regions; Forró de pé de serra originated in the Northeast; Funk in Rio de Janeiro; Country Music originated in the Midwest; Amazonian Popular Music and Boi Bumba in the North of the country.

It is understood that the local musical genres are very representative for attracting visitors, as we can highlight: The axé that brings crowds of tourists to Salvador; The samba that attracts visitors both in carnival and in other months of the year, especially to Lapa's ${ }^{1}$ stronghold in Rio de Janeiro; Parintins Festival that has pulsating beats and lyrics associated with Amazon legends among other genres, which takes place in the Parintins town - AM. It is understood that the tourist use of intangible heritage makes music more important in promoting a tourist destination. As mentioned above, it is highlighted how the Amazonian identity came to be more valued with a stronger introduction of the song called boi bumbá, it is because people started to attend more events related to this musical genre that originated in Parintins city - AM in the late 80 s.

The Brazilian magazine Radar Amazônico (https:// radaramazonico.com.br/musica-popular amazonensese-torna-patrimonio-cultural-imaterial/, retrieved on January 09, 2021) says that another striking factor in the Amazon region, especially in the capital of Amazonas, was the introduction of Amazonian Popular Music - MPA, which was recently declared intangible heritage by the Legislative Assembly of Amazonas by $\mathrm{PL} \mathrm{n}^{\circ}$ $385 / 2019$. Thus, MPA became a cultural asset that must be preserved by the state and society, as it constitutes an important element of identity for the Amazonian people. It is emphasized that one of the places in the Amazonian capital more reveal the Amazonian Popular Music - MPA is Tacacá na Bossa which happens in Largo São Sebastião around the Amazon theater, regional restaurants and souvenir shops.

It is known that since childhood, music plays a fundamental role and it is understood that during adolescence there are more discoveries and affinities with some musical genres. Thus, one wonders is; how does music influence the issue of cultural identity in a location?

Some questions are asked about the research, such as: How did Tacacá na Bossa originate? What are the main characteristics of manauara music through local artists? And how does the Tacacá na Bossa event influence the local cultural identity?

Regional music in Manaus is not famous as in other destinations, but Manaus has a historical collection and music-related events, which may be some factors in attracting city residents to Largo São Sebastião in search of cultural events, or even attract tourists to the city. From this observation, the following issue arises: "How does Manaus music influence the cultural identity of the residents, through the event that happens at Largo São Sebastião called Tacacá na Bossa?". This theme choice is due to the fact that manauara music is present at the Tacacá na Bossa. In addition, it has had a direct connection with the city's residents through the event, also with tourism in Manaus. Taking into account the location of the event as a tourist occupation, there are solo artists and bands that emphasize in their songs the manauara culture through their lyrics

${ }^{1}$ Lapa is a place in Rio de Janeiro where it concentrates several bars that deal with the musical genres of Rio de Janeiro city. The arches of the Lapa are one of the postcards of Rio de Janeiro, which is one of the greatest architectural styles of Brazil Colony. 
and instruments.

Understanding that associating music as an element that influences the place identity is super relevant, since what makes up the local heritage are the cultural patrimony (which associates the immaterial and the material) and the natural ones, which make up the tourist local products and then the tourist offer becomes more attractive.

Addressing the musical influence in the cultural identity formation is essential since music is part of human's life. It is present in various forms of socialization such as religion, parties, work, games, among others. According to Menezes (2011), among the countless musical forms, popular music in its many variants is certainly the one that most rocks and accompanies different human experiences. According to this historian, this is possible because it has the power to convince, to accompany us daily, as an authentic soundtrack of our lives, manifesting itself without distinction in individual or collective experiences. Menezes (2011) adds that popular music is an artistic expression containing the power of communication, which in the urban context has reached a wide dimension of social reality.

The creation of this study was born from experiences lived at the Tacacá na Bossa event that starts in 2016. It was observed that local artists gather at Largo São Sebastião to play their copyrighted music, noting that the event's audience is divided in Manaus' natives and tourists who were getting to know the tourist attractions in that area. These first experiences in 2016, showed us new local bands and artists in Manaus, and the interest in knowing how they influenced Manaus culture.

We believe in this subject-matter because music is a communication method, which allows the listener to reflect on the lyrics. For that reason, it gives meaning and can even reveal universes of human relationships built historically and socially in a context of its own origin. In an easy way music plays the role of interaction between listener and speaker.

Menezes (2011) explains that popular music can constitute a collection, a rich source to know better or reveal obscure areas of the daily life and life stories of a given society.

Believing that this theme is essential for the course because it deals with intangible cultural heritage, which can be as theoretical and reflective support for society and for university. For the researcher, it is interesting because of the importance of studying music as a cultural identity. On top of that, how valid will the research be to increase cultural tourism in the city of Manaus.

For this research, the general goal is to analyze the influence of manauara music on cultural identity through the Tacacá na Bossa event that happens at Largo São Sebastião. The specific goals are: Identify the historicity of Manauara music and the Tacacá na Bossa concert;
Researching the main characteristics of manauara music through local artists, bands and analyzing the importance of the musical event Tacacá na Bossa for residents as a form of cultural identity. The article is divided into: introduction; development; methodology; result and conclusion.

\section{COMMUNItARIAN tOURISM AN ENTREPRENEURIAL PROPOSAL FOR CULTURAL AND ENVIRONMENTAL VALUE}

Tourism is a socioeconomic phenomenon appointed as an alternative to promote regional, local or situated economic development, supporting, in some cases, conservation and maintenance strategies for natural and cultural environments, especially related to traditional populations that are in situations of vulnerability.

Considered one of the largest activities in the economic sector, tourism represents $10.4 \%$ of the world GDP, with $3.2 \%$ being generated directly by the sector and the remainder by activities related to the tourism production chain. It is estimated that for every 10 jobs created, 1 is related to tourism (World Travel and Tourism Council, 2018).

Considered one of the countries with the greatest natural and cultural patrimony, with biodiversity considered one of the richest on the planet, Brazil attracts thousands of tourists every year. With its territorial extension and its biodiversity largely preserved, the Amazon has become a desired destination, exerting a real fascination on the imagination of Brazilian and foreign tourists who come in search of natural and cultural experiences.

Nature tourism represents a strong trend in the current tourist movement, increasing the already growing demand in the search for recreation in natural environments that can offer direct contact with nature and with the populations residing in these environments and, as a result, it is appointed as relevant to the growth of tourism. (Brumatti, 2014; Hall; Müller; Saarinen, 2009; Marzuki; Rofe; Hashim, 2014; Winter, et al., 2020).

Besides contributing to the growth of tourism, TBN is also considered one of the types of tourism that contributes the most, in relation to other types of tourism, such as nature tourism, ecotourism, adventure tourism and communitarian tourism (Buckley; Pickering; Weaver, 2001; Hall \& Boyd, 2005; Mehmetoglu, 2007).

According to a survey carried out by the Brazilian Tourism Company - EMBRATUR (2018), the interest 
in nature, sun and beach tourism, as well as sustainable tourism and ecotourism, are on the rise, with a growth of $27 \%$, pointing to be one of the main reasons for traveling to Brazil. And, through the Tourism Market Intelligence Bulletin - BIMT (2018), the tourism motivation of the Amazon Region is centered on ecotourism. These, among other situations, lead us to believe that the greatest appeal of the destination is in fact the nature and culture of residents in natural environments and, consequently, communitarian tourism.

Thus, Silva, Chaves \& Simonetti (2020) highlight that between ecotourism and cultural tourism, emerges community or community-based tourism, as it is also called, in which, they are based on the role of communities during their management, as well as in the effectuation of tourist activities, with the generation of income divided equally.

"In Amazonas, some communities have adopted the term communitarian tourism in the self-definition of tourist activity in their spaces, whether riverside or indigenous, perceiving tourism as an economic alternative" (Silva, Chaves and Simonetti, 2020, p. 475). Bursztyn (2014) observes the importance of the relationship between the resident, visitor and natural environment, in which communitarian tourism is evidenced by favoring cultural and environmental exchange in a way that is not as devastating as traditional or mass tourism.

Thus, communitarian tourism has been identified as a proposal for the protection and conservation of the natural environment, as it contributes to local development by valuing the culture linked to the situs of each location, as opposed to mass tourism (Bursztyn, Bartholo \& Delamaro, 2009).

It is noteworthy that world tourism is gaining new formats, distinct from the dominant tourism and tourist consumption (Zaoual, 2006). The tourist demand has become increasingly demanding in the search for more versatile and varied experiences, adding value of belonging to the visited place, which provide affective memory and cognitive emotions. "The crisis of the reign of quantity opened the door to quality", which does not prioritize the quality of material service, but rather the experiences, emotions and memories of intercultural and environmental exchanges experienced by tourists.

Communitarian tourism came from a movement of traditional populations with the objective of not remaining on the eminence of "losing their rights to exist and to simply maintain their way of life" (Bursztyn, 2014, P. 61). Allied to the process of "sustainable selfmanagement of community patrimony resources, in accordance with practices of cooperation and equity at work and in the distribution of benefits generated by the provision of tourist services" Maldonado (2009, p. 31 ) considers that communitarian tourism adds gains that go beyond profit and competition, a primordial component for the driving force of capitalism.
According to Maldonado (2009), communitarian tourism has some characteristics that distinguish it from conventional tourism: self-management of community patrimony resources, equitable work cooperation, equal distribution of benefits, encouragement of interculturality through knowledge of the way of local life, having the human and cultural dimension as a preponderant factor of the activity.

Considering that communitarian tourism can develop other socioeconomic mechanisms that are better suited to reality, pointing out other social actors that differ from the capitalist entrepreneurial figure, this study intends to verify other conceptual forms of entrepreneurship that are better suited to the economic experiences present in activities related to tourism developed in the Bela Vista do Jaraqui community, with the intention of presenting the local entrepreneurial reality, in order to help managers, employees and partners in the strategies to support the socioeconomic development of it, as well as other community realities.

\section{MUSIC AS AN INTANGIBLE HERITAGE}

The Brazilian magazine Isto É (https://istoe.com.br/ reggae-entra-para-lista-de-patrimonio-imaterial-dahumanidade/, retrieved on May 10, 2019) says that music can be recognized as a people's intangible cultural heritage, whether by the rhythm, the song lyrics, dances and even the cultural events in a certain place. In a simple and contagious way, music can involve the residents in a city and even attract tourists. All over the world we have examples of how music has become a reference in terms of intangible heritage. In 2019, the reggae music style from Jamaica and known worldwide was recognized by UNESCO as an intangible heritage of humanity, for its contributions to the world's music's history and for bringing in its lyrics the discussion on politics, resistance, injustice, love and social problems. In Brazil, music has a great diversity, from north to south it is possible to identify many musical genres that make the population and tourists consume that music. For Alves (2011), Brazilian Popular Music, in its most diverse representations, provides current and future generations with access to expression, to the face of those who made and makes the Brazilian cultural fusion one of the most expressive musical expressions of the planet. Furthermore, without a doubt it is the flagship of our culture, the most comprehensive and popular form of Brazilian people expression, intangible heritage of our cultural formation. Alves (2011) explains that it is in music that we can experience the presence of the different ethnic strands that make up our Brazil. 
The spectacular thing is that the Portuguese language does not have a structure or sound accessible to outsiders and strangers, but in extreme opposition is the ability of Brazilian music to penetrate the most diverse cultural niches, on any continents, in a testimony of that melody, rhythm, in communion with the words of our language, exert a sovereign power of seduction to the ears, in an almost inexplicable harmony that gives us the grace of having great classical masters such as Heitor Villa Lobos or Carlos Gomes as well as the samba in its greatest expression: the carnival. (Alves, 2011) The cited author clarifies that even within these apparently irreconcilable genres, it is possible to notice the master Villa Lobos's concern in collecting the simplest popular expressions, sounds that refer to cultural origins, productions of local knowledge, valuing country and regional traditions while seeking to break the limited standards of creation.

Brazilian music has several sides, plenty of musical genres, for example samba. It is understood that Brazil is a factory of samba masters such as: Angenor de Oliveira, the icon Cartola, Nelson Cavaquinho, Paulinho da Viola, poets connoisseurs of our language - some of them are instinctively, others are careful scholars of the linguistic structure that governs our native language, such as Caetano Veloso and Chico Buarque de Holanda.

Sabra (2018) says that Brazil is made of many sounds. There is no lack of musical variety in the country, which had influences from everywhere - from Europeans, Africans and native Indians. Samba, Forró, Axé, Country, Funk, MPB are just some of the musical styles heard by Brazilians. Folk music is also part of the culture, such as circle and lullabies, recognized by almost everyone.

The main discussion in this work is about how music can be seen and understood as intangible heritage and how it generates an influence on Cultural Tourism in each city. Nowadays, with easy social media access, people are looking for destinations that have something that refers to this place. In addition, they are going to these tourist destinations to experience something that is the people's cultural identity, and this is reflected in the music and in cultural events.

\section{AMAZONIAN POPULAR MU- SIC- MPA}

The MPA started to be introduced in the early 70's and mainly in the 80's with the introduction of music festivals as a university festival at the Federal University of Amazonas - UFAM, which at that time was called UA, as in the Parque Dez Summer Festival and in the Music Festival of Itacoatiara known as FECANI. With the intro- duction of these festivals came the creation of a radio program created by radio broadcaster Ney Amazonas, who noticed that the artists who performed were usually already known in bars in the city's nights and already had an audience appreciating the type of music they played and in the way they presented themselves, which most of them were own authorship.

From that point, Ney Amazonas had the idea of presenting a proposal for a radio program aimed at broadcasting what was most played in Manaus bars in order to promote the name of the artists as well as the city's musical production. The program called Toque de Bar was started on Rádio Novidade FM, current radio MIX. According to the broadcaster, the repercussions of the program brought interest from listeners and even from several artists, who came to understand that the program served as a showcase to promote their songs, compositions and talents (Menezes, 2011). The author explains that the MPA label started to define the music which was made by local composers now transmitted on the radio. The artists assimilated this designation as something positive for the dissemination of their compositions, because they saw that even the audience understood and appreciated, and the songs were successful.

The Brazilian magazine Radar Amazônico (https:// radaramazonico.com.br/musica-popular amazonensese-torna-patrimonio-cultural-imaterial/, retrieved on January 09, 2021) says that amazonian popular music presents in its lyrics themes that are characteristic of the Amazon region emphasizing the daily life of mestizo, black, indigenous caboclo men, city men, and migrants; as well as aspects related to nostalgia for the countryside and passion for the city, customs regional, festivals, beliefs, folklore, legends, the river, the forest, animals and other reasons that inspire musicians and composers to produce music.

Based on the above musical characteristics, we can highlight the famous Porto de Lenha music by Aldísio Filgueiras and Torrinho.

\section{Porto de Lenha}

Porto de Lenha tu nunca serás Liverpool com uma cara sardenta e olhos azuis Um quarto de flautas do alto Rio Negro, pra cada sambista, que sonha sucesso Sucesso sulista, em cada navio, em cada cruzeiro, em cada cruzeiro das quadrilhas de Turistas.

The MPA became a cultural heritage of an immaterial nature by the Legislative Assembly of Amazonas through PL no 395/2019.

The Brazilian magazine Radar Amazônico (https:// radaramazonico.com.br/musica-popular amazonensese-torna-patrimonio-cultural-imaterial/, retrieved on January 09, 2021) says that it is reported that one of 
the characteristics of MPA is the use of multiple expressions and typical terms of the region present both in the urban environment and in the countryside, including: "Banzeiro", "Curumim", "Leseira", "Mano", "Maninha", among others. The analysis of these themes present in the songs lyrics and in other extramusical aspects, such as the context of their production, the musicians and composers paths among other situations. Consequently, making it possible to recognize a distinct musical profile which at the same time establishes a dialogue with Brazilian Popular Music.

We highlight typical terms that are introduced in the composition of Anibal Beça and Armando de Paula in Marapatá song.

\section{"Marapatá", de Armando de Paula e Aníbal Beça}

"Que doce mistério/ Abriga teu dorso/ De ilha afogada/ No curso das mágoas?/ O velho Bahira/ se mira nas águas/ Espelho da lua/ Narciso nheengara/ (...) Que mana maninha/ Que dança sozinha/ Savana de seda/ Pavana de cio/ Capim canarana/ Bubuia ban-

zando/ Canção enrrugada/ Banzeiro de rio. (...) Cunhã se arretando/ Tesão de mormaço/ Abrindo as entranhas/ A flor de tajá/ E o macho fungando/ Flechando, fisgando/ Mordendo a leseira/ Dizendo: "Ulha já!".

Another song that characterizes the Amazonian culture is the music of Nicolas Jr.

\section{Amazonês - Nícolas Jr}

Espia maninho/Eu sou dessas paragens/ Das 'banda' de cima/ 110 Do lado de cá/Eu não sou leso/Nem tico bodó/ Mas boto no toco/Se tu me 'triscá' (marrapá)/ Eu não vim no guaramiranga/ Sou moleque doido não venha 'frescá'/ Pegue logo o beco e saia vazando Senão numa tapa tu vai 'emborcá'/ Me criei na beira ali pelo 'ródo'/Eu me embiocava lá pelos 'motô'/ Mamãe me ralhava e eu nas 'carrera', zimpado/ Era galho de cuia, lambada e o escambal/ Saía vazado pro bodozal, menino vai se 'assiá'/ Tira a tuíra do 'côro', que agora é dos vera/ Vou te malinar/Sou amazônes, não nado com boto, nem chupo 'piqui' Sou do mesmo saco da

farinha/ Aquela da ovinha ali do uarini/ Sou amazônes, num é 'fuleragi'/ Eu sou bem dali e dou de 'cum força' na farinha/E sou 'inxirido até o tucupi. Eu era escarrado e cuspido uma osga/Mas meu apelido era carapanã/ Era chato no balde, um cuirão pitiú/ Mais 'intojado' que 'dismintidura'/ Numa gabolice pai d'égua que só, pois num é?!/ Man eu era chibata, parente, de rocha/ Era o rei do 'migué'(sou amazonês...)/Na ilharga das balsas Brincava de pira/E ali de 'bubuia', ficava até 'ingilhá'/ Mangava 'dusôtro' na esculhambação/ E na hora da broca mandava dindin com

kikão/ Era bom 'qui só' Eu pegava um boi, que era massa demais/ Égua 'su mano', eu cresci à pulso E hoje vivo dos bicos na rampa dos cais (sou amazonês...)

These songs mentioned above represent the Amazon place and the cultural characteristics of the northern region.

In the Amazonian capital, MPA registers the dynamics of a city in growth and transformation. Ironically and critically contextualizing the new realities, the music expresses in its lyrics the issues related to these transformation processes. (Menezes, 2011).

We can emphasize that the main MPA outstanding singers were: Candinho and Inês, Cileno, Antônio Pereira, Renatinho, José Evangelista Torres Filho known as Torrinho, Lucinha Cabral, Nicolas Jr and others.

One of the positive things about the MPA was drafting the law 3.247 which requires the allocation of $10 \%$ of the radio stations programming in Amazonas state to broadcast the works of Amazonian artists. (Journal Daily Amazonas, 2008 as cited in Menezes, 2011).

\section{METHODOLOGY}

This stage will show the steps that were taken to answer the specific goals thus, the methodology is a set of rules and methods. Gil (2006) emphasizes that it is in the methodology that the researcher must clarify the procedures to be followed in carrying out the research. The author highlights that organization varies according to the peculiarities of each research, therefore it is required that such procedures be described as: as regards the approach, it is qualitative, as there is a need for interpretation of phenomena and definition of meaning, which are associated in the analysis of the influence of Manaus music on cultural identity through the Tacacá na Bossa event that happens at Largo São Sebastião.

For Goldemberg (1999) qualitative research is a specific technique. However, it is a holistic analysis that seeks to gather the greatest amount of detailed information, through different research techniques in order to learn the totality of a situation and describe the complexity of a factual case. Nevertheless, through a deep dive and exhaustiveness in a delimited goal, the case study allows the penetration into social reality, not achieved by statistical analysis.

It is mentioned as quantitative because it works with numerical data such as: analyzing the importance of the musical event Tacacá na Bossa for both residents and tourists in the city of Manaus.

It is mentioned that the methodological objectives are: exploratory, due to the fact of knowing the subject not in depth. It is also descriptive for describing the characteristics of the goals such as: analyzing the historicity of Manauara music and the Tacacá na Bossa event; 
Search the main characteristics of music in Manaus; identify current solo artists and bands in Manauara music; And analyze the importance of the musical event Tacacá na Bossa for both residents and tourists in the city of Manaus.

It is descriptive because it details the main historical characteristics of the Manauara music and the importance of the Tacacá na Bossa event for their cultural identity.

The exploratory research aims to identify information and subsidies for defining the objectives, determining the problem and defining the topics of the theoretical framework. This type of research seeks to provide better familiarity with the problem in order to make it more explicit or to build hypotheses. It can be said that this research has as its main idea the improvement of ideas or the discovery of intuition (Michel, 2009).

The author reports that descriptive Research aims to verify and explain problems, facts or phenomena in real life as accurately as possible by observing and making relationships, connections, in light of the influence that the environment exerts on them. It Does not interfere in the environment; its objective is to explain the phenomena, relating to the environment.

The sample is intentionally non-probabilistic as the concern to formulate the problem came from the researcher due to the observation that the Tacacá na Bossa event, that takes place in Largo São Sebastião, has a specific yet not so frequent audience. What is more, both public can help to understand Manauara music as a cultural identity. Also the sample was aimed at the public that attends Largo São Sebastião on Wednesdays, the day of the Tacacá na Bossa event, and the sample size can vary around the day's attraction. For this interview, a sample of 30 people through questionnaires was used.

In data collection, tools were used such as: Questionnaire and forms that were applied to the creators of the Tacacá na Bossa event and to the general public that participates in the event; structured and semistructured interviews with musicians who make up the current music scene in Manaus, in audio and video format carried out by the meet platform.

Data analysis was performed using images and graphics that helped to better describe the results. Therefore, it is believed to give more confidence in the veracity of the research. The technical procedures are of a bibliographic and case study order, as the bibliographic materials used were: Heritage Books; Musical; Amazon History; Articles and others.

The case study took place at Largo São Sebastião (Figure 1) which is located at Avenida Dez de Julho downtown Manaus, on nights of Tacacá na Bossa event. It is also highlighted that the event receives support from the tacacá stand, called "Tacacá da Gisela" which is located around Largo São Sebastião, where Amazon Theater, one of the best tourist attractions in
Manaus is located.

Figure 1 - Advertising poster Tacacá na Bossa

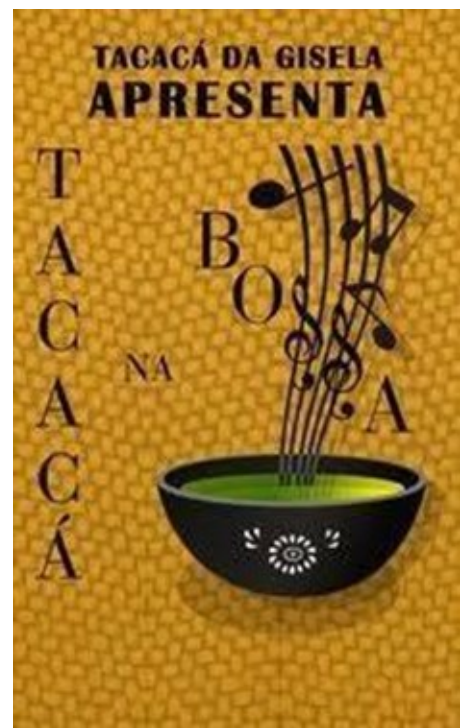

Source: Tacacá na Bossa (personal communication, April 1st, 2011).

\section{RESULtS}

\section{The Tacacá na Bossa event}

The event Tacacá na Bossa, was created on the initiative of Joaquim Lopes around 2005 (Figure 2), for being a music lover mainly from Bossa Nova, he decided to create a space next to Tacacá da Gisela where musicians gathered to play while the regulars took the famous Tacacá.

Figure 2 - Tacacá na Bossa in 2005

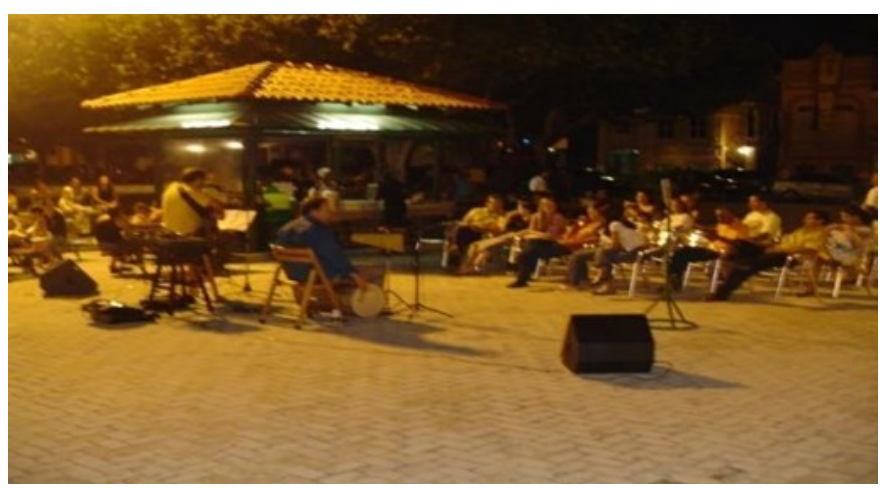

Source: Joaquim Lopes (2019).

The Tacacá na Bossa's name came from the sale of the delicacy that is typical of the northern region. The tacacá (Figure 2) which is a yellowish broth, called tucupi. This broth is placed on top of the cassava gum, also 
served with jambu and dried shrimp. It is noteworthy that it is a cuisine very appreciated by the cities in the north of the country.

Figure 3 - Typical Amazonian food: tacacá

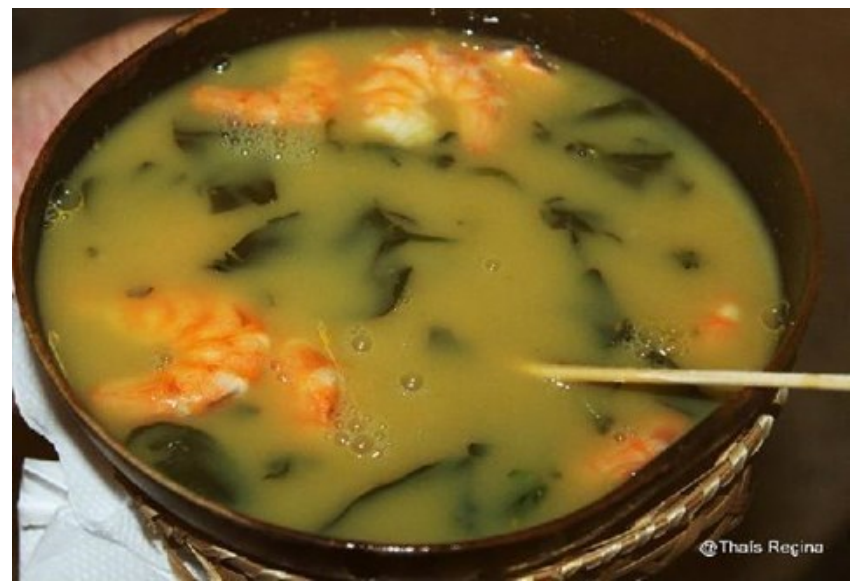

Source: Tacacá na Bossa (personal communication, 2011)

In 2004, Largo São Sebastião had been transformed into a public cultural space, so almost every day there was some kind of cultural event. In 2005, Largo São Sebastião, which was recently refurbished and transformed, monitored by the Secretary of Culture - SEC, at the time having Mr. Robério Braga as secretary, began to enter into a process of few cultural events.In June 2005, Joaquim Lopes (founder of the event) started holding the event next to the "Tacacá da Gisela" tent, where musicians would gather and play their music in a very simple and appreciative way.

The Secretary of Culture - SEC was one of the first support partnerships the event obtained providing the space and chairs for the small audience that was there. The event always happens on Wednesdays because when Largo São Sebastião had been refurbished, there were events happening every day, and Wednesday was the only free day, so Joaquim Lopes (2019) decided to do the event on that weekday.

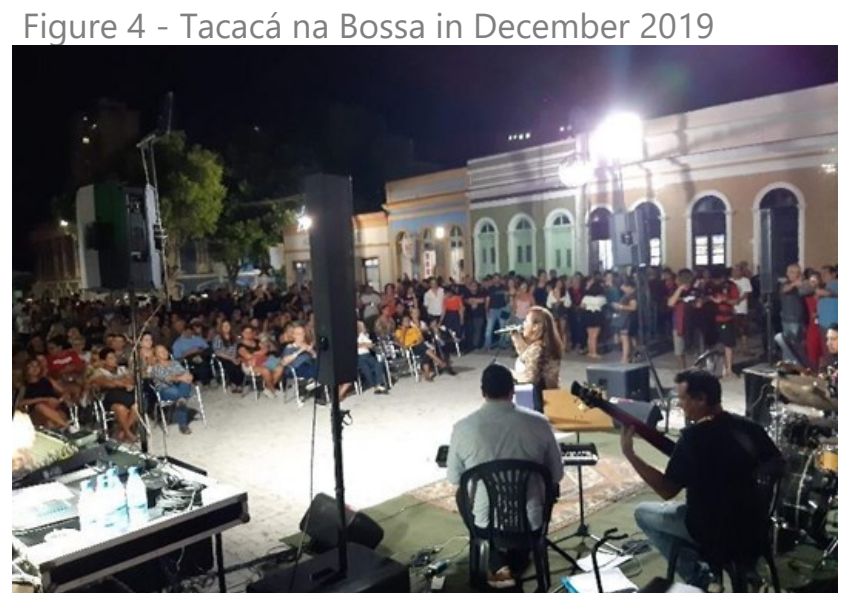

Source: Leonardo Gama (2019)
The purpose of the event was always to make people enjoy good music while drinking their tacacá. As time went by, this audience began to grow, occupying not only the surroundings of the Tacacá da Gisela tent, but also occupying the central area of Largo São Sebastião (Figure 4).

The event has already received national artists Ed Motta is an example of that. He is one of the great names of Brazilian music. According to the event's creator in an interview with acritica.com ${ }^{2}$. He says that "our purpose was to bring quality music to the public. We started only with bossa nova, which is why we invited Paulinho Bossa Nova to start the project" (Joaquim Lopes, 2012).

Realizing the proportion that the event took, Joaquim (2019) began to include local artists in the program because he saw a way to make the work of local musicians appreciated by city dwellers and tourists. To the acritica.com he said "the project has just become a reference space for local musicians to show their work, and they understood perfectly what was happening" and adds "I think the important thing for those who work with cultural activity, as in our case, without profit, is to be honest with those who make music" (Joaquim Lopes, 2012).

Many local artists have already gone through Tacacá na Bossa, artists who used the event to promote their new album, such as: Banda Alaídenegão in 2017 made a special edition of the event to promote the new $C D$ "ALAÍDENEGÃO" (Figure 5) thus taking a large audience for the event (Figure 6).

Figure 5 - Art for publicizing the special edition at Tacacá na Bossa

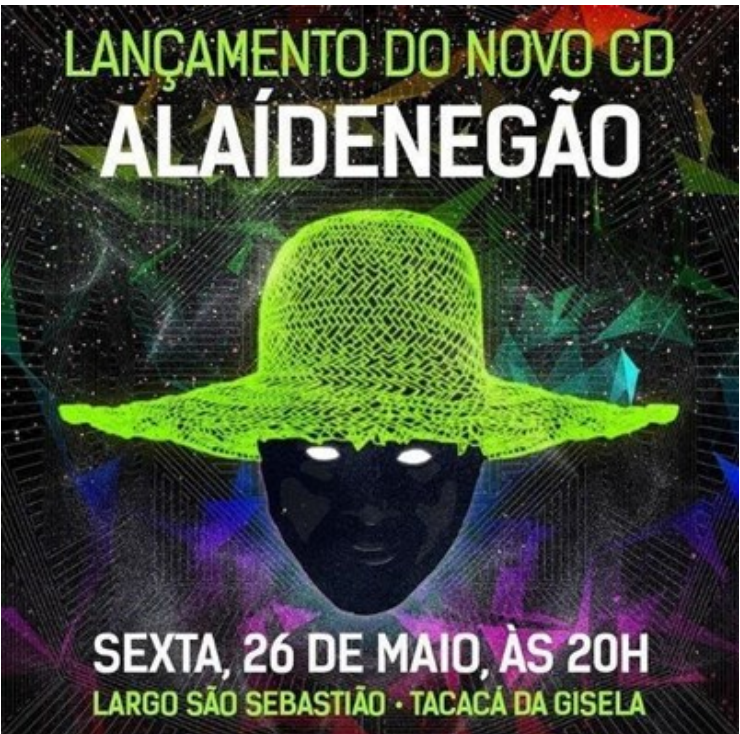

Source: Alaídenegão (personal communication, 2020).

${ }^{2}$ Excerpt from the interview taken from the newspaper arti cle: Tacacá na bossa has been making good music since 2005. Available at: https://www.acritica.com/channels/ entretenimento/news/tacaca-na-bossa-leva-boa-musicasince 2005. Accessed on: 14 Jan. 2021 
Figure 3 - Alaídenegão launch show in 2017

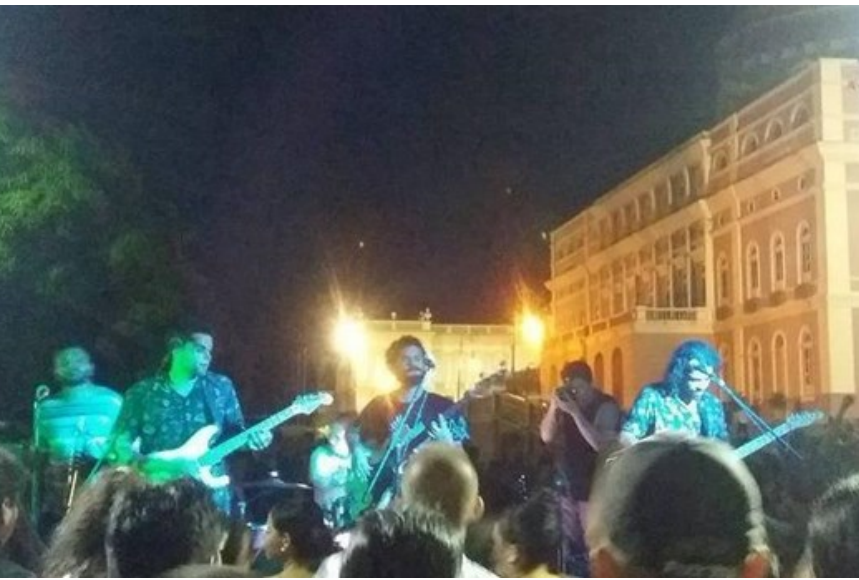

Source: Leonardo Gama (2017)

For the Band Alaidenegão, the Tacacá na Bossa event: they are always the best shows of the year [...] due to the proximity of the public [...] the accessibility, the tacacá (na Bossa) is horizontal, ranging from the guy who doesn't have money to go home, the guy who's going to add a can for recycling to the guy who pays the same ticket as the all night and is there with his friends [...] it's a hot show, a delivery show, the audience is on top, sings and dances [...] tacacá na bossa is resistance, a credit to Joaquim (founder of the event) (Davi Escobar, 2021).

The band's first show happened in 2012, the event was still without a stage, but with a "gang" wanting to enjoy the band's show that was still inserting itself within the Manaus music scene.

For the band Cabocrioulo, playing at Tacacá na Bossa "has always been a very cool place to play" and that "the best place to play is on the street, on the floor in front of the audience" (Milton Cabocrioulo, 2021), details that just happen at the event. Marcos Cileno (2021) compares Tacacá na Bossa as a showcase, as it is a place where local artists exhibit their work to the Manauara public and also to tourists.

Marcia Novo singer has constantly been one of the attractions that manages to bring a large amount of audience to Largo São Sebastião during the Tacacá na Bossa event. For her the event is:

Having a place where we can show our art in the center of Manaus with a nice structure is very cool. In addition to making this music, this art spread throughout the city, that's very cool. I think it's fundamental, I think it's a project that can't stop. I think it's a fundamental project for authorial music here in the city. I've played there many times and my feedback has always been very positive" (Novo, 2021).

Marcia Novo also uses the event to promote her work, release albums and shows. One of her latest participations in the event was to record a live album, the recorded show will contribute to the dissemination of both the artist and the event Tacacá na Bossa. Over its 14 years of performance, Tacacá na Bossa managed to be included in the main event that takes place in Manaus, but much more than that, it gave local musicians the opportunity to be included in the music scene in the city which has boosted their careers. The event brought to residents the identification by the local culture and music; and tourists the opportunity to learn more about what kind of music is appreciated in Manaus.

\section{The Tacacá na Bossa event and its importance to Manauara music from the regulars' view}

The Tacacá na Bossa event brings a very expressive audience to Largo São Sebastião during Wednesday nights, to whom enjoy the event. Among this audience, there are types of attendees: those who are regulars at the event; those who attend when there is a specific presentation of some genre, artist or band; and finally those passing through Largo São Sebastião, including tourists visiting the city.

During the Tacacá na Bossa event on May 15, 2019, we applied a survey to attendees; closed form questions that made it possible to identify some important factors for the development of the survey. Thirdy people who were enjoying the Tacacá na Bossa event in Largo São Sebastião have been interviewed.

As a result, we obtained the following data: $87 \%$ of the interviewed people were residents of Manaus, which is equivalent to 27 residents and 3 tourists. Taking into account that the estimated number of people attending the event can vary according to the attractions.

Figure 7 - Manaus City Residents

\section{MANAUS CITY RESIDENTS}

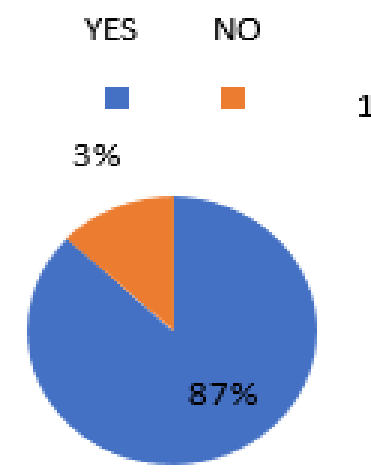

Source: Gama (2019) 
Interviewed people reported that: 2 people reported they discovered the event through newspapers; 12 people through other channels, take an example, these people who were passing through Largo São Sebatião and it was Wednesday and staying there to appreciate it. It is valuable remembering that this attitude of stopping to watch the presentation at Tacacá na Bossa can influence the person to become a regular attendant; 9 people got to know Tacacá na Bossa through friends, which proves that people who are already regulars share about the event with friends; and 4 reported that they met on the internet, mostly on

Figure 8 - How the public knew about the Tacacá na Bossa event

\section{HOW THE PUBLIC KNEW ABOUT THE TACACÁ NA BOSSA EVENT}

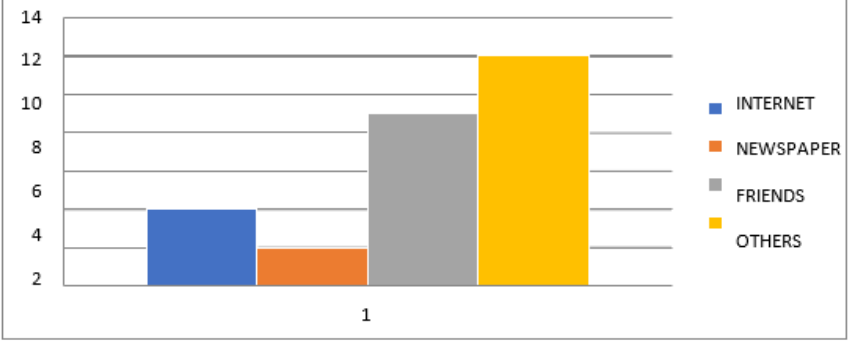

Source: Gama (2019)

social networks.

Talking about the frequency of respondents; 11 of them reported they attend the event at least once a month; the other 16 people are distributed in attending 3 times a month or every Wednesday of the month not missing any event. Relating to the facts it could conclude that the majority are regular attendees of the event.

Figure 9 - Attendance at the Tacacá na Bossa Event

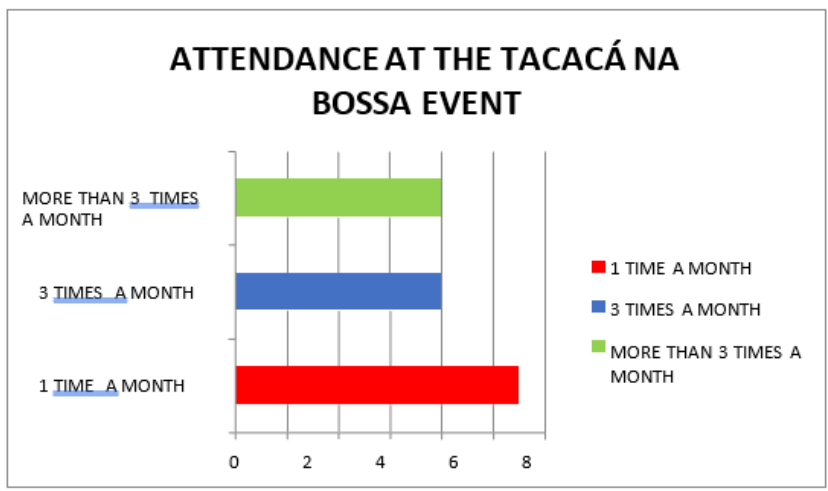

Source: Gama (2019)
One of the questions on the form was whether these people really knew regional music; $48 \%$ said they have known at a high level about the music of Manaus, $41 \%$ said that they have known at a reasonable level, and $11 \%$ answered that they have known little about manauara music. It shows people who attend Tacacá na Bossa have a high level of knowledge about manauara music and this ends up explaining why these people are so present at the event, to honor the artists they like the most.

Figure 10 - Level of Knowledge related to Manauara Music.

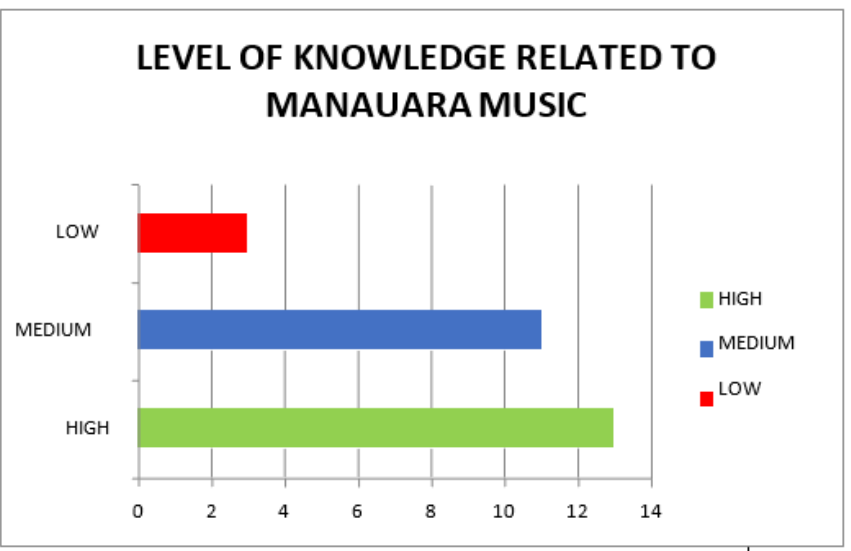

Source: Gama (2019)

The main characteristics of manauara music throughout local artists and bands

Based on analyzes made in the songs and interviews of the artists mentioned in this research, it is possible to affirm that there are two main characteristics that are extremely important for the recognition as a cultural identity by the residents, which are: the lyrics and the genre that make up the song.

Lyrics for using slang, with typical amazonian words, such as: Tu é Leso; Jaraqui; Rabeta; Pavulagem; maninho; maninha; curumin; banzeiro and others are contained in the songs. Singer and composer Marcia Novo (2020) recognizes when typical terms are used in songs, people hear and generate a cultural identity because they realize that they use the terms in their daily lives, and this also happens when talking about the resident's daily life. Whether in the countryside or the capital because when you mention in a song how good it is to take a "river shower" in the Rio Negro or even talk about the Manaus heat, listeners identify with the lyrics.

The band Alaídenegão mentioned in this research is an example of this, as their songs exercise this function of identity as the lyrics. According to the vocalist's words: "I think it's clear on the lyrics, when we talk about Praia 
da Lua, when we talk about some jargon ${ }^{3}$ and characteristic things, like "nem com nojo" this type of jargon makes a Manauara be recognized by other Manauara in any part of Brazil (Davi Escobar, 2021).

The band's most popular songs are: Banzeiro na Areia; Tecendo o Som; Batom na Cueca; Macuxi Muita Onda; Cadê a Morena; Piranha; Cadê a Morena; e A Rabeta. All these songs emphasize the genres with typically Amazonian lyrics the band uses. This combination plays a very important role because when the band performs in other places, there is always a manauara who goes to the show to remember a little bit of their hometown. Davi said that at the end of the show it is common to hear something like "today I went back to Manaus for old times' sake at your show".

For example, the song Banzeiro na Areia, was born of experiences the band's musicians have lived (2021), portrays the festive daily life on the outskirts of the city:

"Tava na beira da praia pegando um vento do oeste quando sentar nessa mesa não saio nem que me carregue viver a vida correndo".

And in the same song, significant places from a city are emphasized, such as the Church, the Tacacá tent in the square:

"No arranca rabo no meio do mato alto eu fui tentado olhando a esquerda ela viu a cruz da igreja: pediu uma breja.

Numa barraca de tacacá lá na praça eu fiz a feira". Another significant song for an interpretative analysis as cultural identity, which also portrays characteristics of the Amazon region, is "A rabeta". Composed by musicians who are currently part of the band: Davi Escobar, Anastacio Ferreira and Rafael Angelo, along the song's lyrics the influence of what happens along the Amazon rivers' edge is noticeable by exploring aspects of the the riverside lives, the dolphin; according to Davi Escobar (2021) this song was born on a return trip from Santarém to Manaus and are described as follows:

Passa a água, passa o barro, a madeira Passa a ponta da ribanceira

Passa a casa, a igreja Passa tudo que mora na beira

Passa o pasto, apressa o passo Passa o boto que leva o cabaço Da menina fazendeira

Da filha do seu teixeira

Vai no tranco da rabeta no remanso Rio novo que leva o barranco

Leva a água, leva o barro, a madeira Leva a ponta da ribanceira

Leva a casa, a igreja Leva tudo que mora na beira

Leva o pasto, apressa o passo Leva o boto que leva o cabaço Da menina fazendeira

Da filha do seu Teixeira.

Considering songs that address manauara life, Alaíde-

${ }^{3}$ Jargon is defined as addictive language. negão band also has in its repertory the song "Rodar na Bica," which alludes to a traditional carnival party in Manaus, as well as describing some places frequented by locals like Armando's Bar. Below we have how it is described:

\section{Ta se arrumando Vai se perfumar Corre pro armando Ta querendo amar Vai rodar na bica.}

Another song that is in the band's repertoire is "Cadê a Morena", which according to the Brazilian union of composers - UBC (2021) was written by Marcelo Nakamura and Agenor Vasconcelos. The song is another classic example of how the lyrics emphasize cuisine, the slang and daily life of the northern region:

\section{Comeu Jaraqui \\ Farinha com Baião \\ Comeu Açaí}

Daqui não sai mais não.

In this first excerpt of the song, some peculiarities of Amazonian cuisine are mentioned, such as the fish called jaraqui and assai, also at the end of the verse there is a reference to a popular local saying "whoever ate jaraqui never leaves here", it is worth remembering that the culinary dish made with this fish was elected in 2019 as intangible heritage of Manaus ${ }^{7}$, following by the song's lyrics owe now have:

\section{Nem com nojo \\ Moleque doido \\ Nem com nojo \\ Você não sai mais não.}

In this second excerpt, the use of the slang "nem com nojo" is notorious, which for the manauara symbolizes a situation that will not happen or that the individual will not do it, it is also a way to deny something.

Finally, the last excerpt brings references to everyday issues that many residents face to:

\section{Atravessou a ponte \\ E foi pra Iranduba \\ Agora da plantão \\ lá no bar da viúva.}

The vocalist Davi Escobar (2021) explains about the above excerpt that "this composition process for the band nowadays is increasingly collective" and adds about using slang in the songs "we talk like that, it's like our daily language".

Like the band Alaídenegão, Cabocrioulo also recognizes that the songs' lyrics are factors in the issue of cultural identity. For the vocalist and composer of the band "the lyrics are very simple, I try to mix the colloquial with the cult. The colloquial language of our daily language, with some words I have learned in high

${ }^{4}$ https://g1.globo.com/am/amazonas/noticia/2019/11/23/ jaraqui-e-reconhecido-como- patrimonio-imaterial-demanaus.ghtml. Acesso em 22 jan. 2021 
school and college" (Milton Cabocrioulo, 2021), to complete, he says that people have questions when they hear the band's sound because these people wonder if it is actually regional. For this, Milton (2021) says that "the regional can be through the letter as well [...] the letter speaks of the river, of the flying boat [...] so we are regional through our language, we say " tu é leso, vamo mesmo" so there's no getting away from it".

The band also has a repertoire which the influence of local culture in the lyrics of the songs is notorious, an example of which are the songs "Manaus Cidade Grande and Costume de Interior Pequeno" which these lyrics bring the discussion about the city's growth, a social criticism, so he says.

\section{Oh! Grande pequena extensão}

Uma parte do Brasil em evolução

Crescimento urbano e um verde se acabando

Onde empresários querem construir gigantes prédios ganhar dinheiro e fugir fazer parcerias e se dar bem". We also have the songs "Banho de rio" and "Pense num calor", both lyrics portray the daily life of manauara, in the first song we have the Rio Negro as a highlight, in the second the "manauara heat" is reported in the lyrics:

\section{Mermo em Manaus \\ Que é muito quente \\ O calor no rio é bom, mas no quarto fechado, pense.}

According to Milton Cabocrioulo's (2021), the song "Pense num calor" was born from sentences that he says in his daily life and that end up appearing in such a natural way. He said the following about the composition of this song: "I was at home and then I actually said in Manaus that it's hot as hell, the heat in the river must be good, but here in the room it's hot" (Milton Cabocrioulo, 2021). It's exactly because of these peculiarities that Manaus music is a fact of cultural identity; it is something generalized that everyone in Manaus thinks in the same way.

The song reports that the heat of Manaus is good when we are in a "bath" ${ }^{5}$, having fun in stream ${ }^{6}$ swaterfalls or rivers, but when we are in the bedroom, this heat is exhausting. Still talking about the song "Pense num calor" is also a cultural manifesto, a way to show how these events happen in the city, from which he mentions the square, that the composer Milton Cabocrioulo (2021) confirms it is a clear reference to the musical event Tacacá na bossa.

Vamo se ligar porque essa noite é nossa

Vamo se ligar porque o evento hoje é aberto na praça Vamo se ligar porque são duas por cinco Nesse manifesto cultural eu vou me jogar

${ }^{5}$ Bath is the name given by manauara to a place such as a beach or water park

${ }^{6}$ BathStreams is a water that flows naturally, place where manauara will have fun
Songs like these are extremely important for the purpose of this research. Regional characteristics that are explicit in the lyrics and that somehow influence the listener to have a perception of the local culture, for a resident or a tourist. The resident makes music as a cultural identity and the tourist uses music as a reference to the city of Manaus.

The singer Marcia Novo (2021) says that the slang used in her songs are the most striking characteristics for listeners to hear and appropriate as a cultural identity. As a composer she is an observer of what she lives and hears in her daily life; that's why there are so many attributions of Amazonian culture.

One of her most important works to the cultural identification by the local public is the album entitled "O Novo Som do Beiradão", launched in 2015. It brought the listeners a sound inspired by the genre of Beiradão, in which the lyrics talk about the manauara and the countryman's lives.

For example, one of the songs called "Já Que Comeu Jaraqui" emphasizes the Amazonian cuisine and how much it influences the people's taste, especially of people who do not live in the Amazon. The song extract says:

A saudade não tem hora
Quando vem não vai embora
quem comeu não sai daqui
Já que comeu jaraqui.

We also have the song "Bariri Vou Lá" that simple verses manages to touch your listener:

Tchu tchururu tchururu tchururu

Tu é leso, é?

Tu é leso, é?

The song brings in the lyrics one of the most known slang words in Amazonas which means something like "you're crazy". Another characteristic that generates this impact is the genre used in music. Today the city does not have a sound of only one genre because local music is a great mix. Both the musicians of the band Alaidenegão (2021) and the band Cabocrioulo (2021) report that for their music there is no definition of which genre predominates, taking into account that in each of their productions, it is always something different, but never without losing the essence of the sound of both bands, becoming an Amazonian sound. For Davi Escobar (2021) vocalist of the band Alaidenegão, "We chose a band's name not to refer to any specific rhythm". Marcia Novo (2021) reports that there has always been a need in her work to use much more the sound of the Amazon in her music, somehow portraying the local culture. According to Marcia, "the time I approached the band Alaídenegão and proposed them for us to come together and record my album, "O Novo Som do Beiradão", and that is when I felt this connection of perfect fit, so that people understood what my proposal was" (2020). For the band Alaidenegão, "O beiradão today is the greatest musical reference [...] 
because that's what we're listening to, it's what we're getting deeper into [...] there's a lot of guitar playing" (Davi Escobar, 2021).

In this mix of musical genres, we have some that are more recognized by the residents, the boi bumbá, the beiradão and the brega (Marcia Novo, 2021), and this agrees to what was said by the event's attendees when they were interviewed for this research The result shows that: $35 \%$ think that Boi Bumbá is the main genre of identification for Manaus music; already 36\% think that Beiradão performs this function; followed by $29 \%$ who mentioned other genres generate this identification, such as brega and forró (graph 05). These genres run specially the big parties in Manaus, including the Tacacá na Bossa which are presented by various artists.

Based on this facts, the next question on the form

Figure 11 - Musical Genre

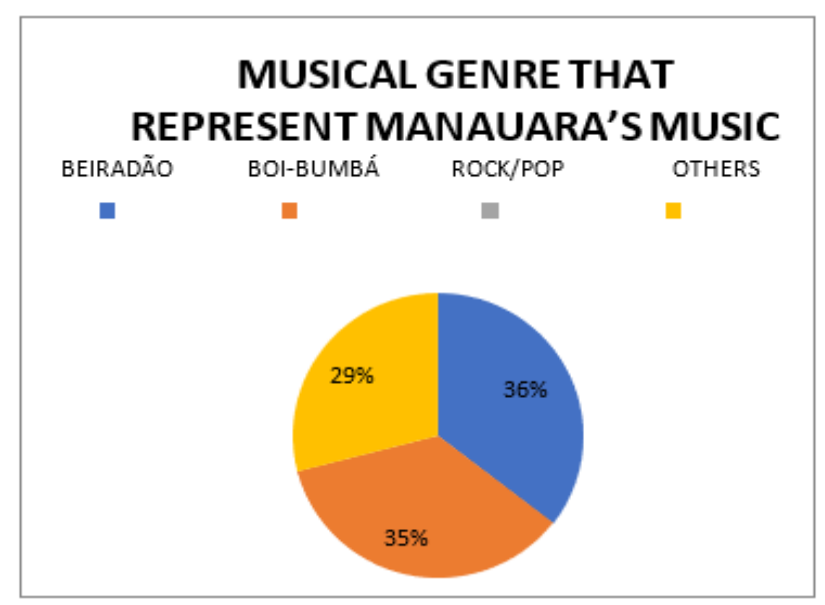

Source: Gama (2019)

asked to Tacacá na Bossa's regulars what was the artists and bands the interviewees knew the most, and the public chose 10 main singers and bands, they are in order by the most voted: Márcia Siqueira who brings in her repertoire all the influence of the boi bumbá; Zezinho Correa ${ }^{7}$ vocalist of the Banda Carrapicho that spread the Boi bumbá to Brazil and the world with the song Tic tic ta, being one of the most played songs in the summer of the 90's in Europe; Cabocrioulo band that brings a mixture of reggae and MPB also bringing in their songs typical Amazonian terms and attitudes; Alaidenegão band that mixes carimbó, brega and rock; Chico da Silva a great MPA musician; Jhonny Jack Mesclados band that sings reggae music; Marcia Novo who

${ }^{7}$ Zezinho Correa was a musical phenomenon in Manaus, he showed Amazonian music to the whole of Brazil, and also to the world with Banda Carrapicho, singing songs of the genre called "boi bumbá". He showed the best that local culture has to offer for the residents and tourists. In addition, he was an assiduous artist singing at the Tacacá na Bossa event. Zezinho unfortunately died on February 6, 2021 from complications with covid-19, leaving a musical legacy. raises the boi bumbá flag mixing it with a pop; Cilenos; The Stone Ramos; and Tucumanus and the last three mix MPA, Brega and Rock but always bringing Amazonian references in their lyrics. All artists and bands mentioned in the ranking are regular attractions at Tacacá na Bossa, and they manage to attract a significant number of people on the day they perform.

Table 1 - Most Cited Artists

\section{MOST CITED ARTISTS}

\begin{tabular}{l}
\hline $1^{\circ}$ - MÁRCIA SIQUEIRA \\
\hline $2^{\circ}$ - ZEZINHO CORREA \\
\hline $3^{\circ}$ - CABOCRIOULO \\
\hline $4^{\circ}$ - ALAIDENEGÃO \\
\hline $5^{\circ}$ CHICO DA SILVA \\
\hline $6^{\circ}$ - JHONNY JACK MESCLADOS \\
\hline $7^{\circ}$ - MÁRCIA NOVO \\
\hline $8^{\circ}$ - CILENO \\
\hline $9^{\circ}$ - THE STONE RAMOS \\
\hline $10^{\circ}-$ TUCUMANUS
\end{tabular}

Source: Gama (2019)

The relevance of the musical event tacacá na bossa for residents as a form of cultural identity.

It was also questioned whether the event brings cultural representation to the people: $97 \%$ of the people interviewed said yes, the Tacacá na Bossa event has great importance of valuing the culture of manauara in

Figure 12 - Representativeness of the Event.

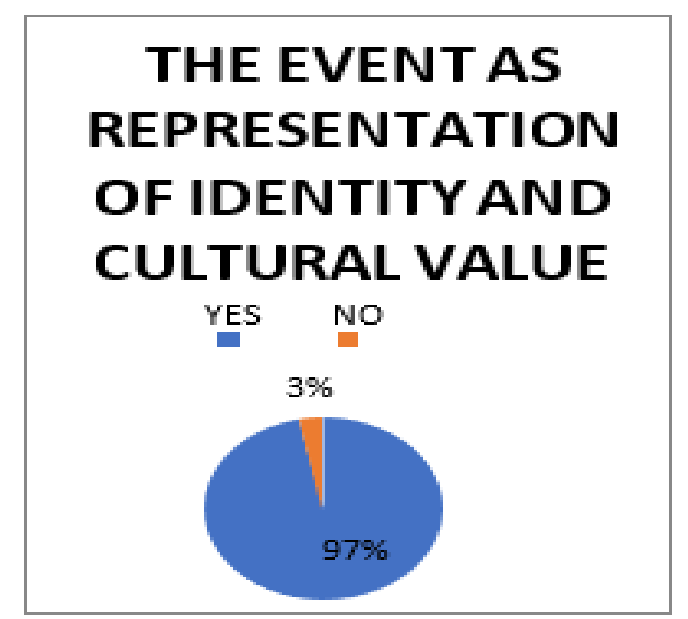

Source: Gama (2019) 
terms of music. And here we have the answer to our problem, more than half of the interviewees answered positively about the event raising the recognition of cultural identity for them as residents. It shows that the event influences the manauara through music to have this representation. In other words, the event is fulfilling its goal: to have local artists performing at Tacacá na Bossa and to make those attendees value these artists. This is the objective of the event and of this research: Tacacá na Bossa, Manaus music and the resident's contact with them.

\section{DISCUSSION}

Understanding music was a key factor for the study of this research. We took as a basis what Fregtman (1986) says "Music is much more than a perfect rhythm: it is the possibility of organizing the sound matter in a way that allows us to communicate the inner dynamism". Taking into account that this sound matter is connected with what we refer to as manauara music, the peculiar sound played at Tacacá na Bossa.

Souza (2009) said: a person's musical identity will be closely linked to "the memories, facts, places, people and feelings". The author states that these details are important to create the musical identity of an individual or of people, and this is in agreement with the issue addressed throughout this research since the general goal is to relate the influence of manauara music to the cultural identity of the city's resident through the event Tacacá na Bossa. The event itself seeks to create this musical identity with the attendees, as the artists, the venue and the experience contribute to the dissemination of this identity with those who are at the event. These peculiarities make this identity seen as an intangible cultural heritage.

According to IPHAN (2003), practices, expressions, instruments, artifacts, cultural places, knowledge and techniques; all of this is what we call intangible cultural heritage. Moreover, when we put in this research the issue of manauara music and the event Tacacá na Bossa as intangible cultural heritage, it is a way of showing that these objects of study can be in fact recognized as which as we have highlighted throughout the research process the way the music and the event happens at Largo São Sebastião.

IPHAN (2006) also emphasizes the issue of the program "Living human treasure", which recognizes "individuals or groups who have knowledge about significant expressions of traditional culture and are important for its reproduction and transmission to new generations" (p.125, 2006). For the researcher to emphasize the importance of local artists in the research, it is to continue based on this definition given by $\mathrm{IPH}-$
AN, since we are talking about musicians who produce music with regional characteristics and perpetuate this music for future new generations, and this already becomes a perspective for future of this research, a deeper understanding of manauara music.

\section{CONCLUSION}

It is concluded that all around the world there will always be some music that will take us to a certain place, whether through sound or even through musical events, music becomes a function of the cultural identity of people. Nowadays, music has influenced the choice of a tourist destination, such as: the experience of music in the destination itself, or even experiencing the music that is the identity of the destination in some event during the trip.

One of the positive things about concluding this study was to realize how music expresses a place and values the tangible and intangible heritage of a location; it also expresses local behavior that through music can be recognized nationally and sometimes even internationally.

We notice that the artists' will of making music is measured by the symbolic exchanges developed in the family, in social groups they attended, and in the access to certain types of music throughout their trajectories, we can understand that it is constituted of a habitus (Bourdieu, 2005 as cited in Menezes, 2011).

The interesting thing is that Amazonian music is created by inhabitants of the region or by people who are familiar with it, as they express the origin of society through the Amazonian experience.

It is revealed that regional music in Manaus is not yet as large as in other destinations, but the city of Manaus has a historical collection and music-related events, which may be factors in attracting city residents to Largo São Sebastião looking for cultural events, or even attracting tourists to the city.

It demonstrates the need for the toadas and MPA to be played more on radios in the capital and in the countryside of Amazonas, and the lyrics of the songs are debated in History classes as a matter of belonging and to elevate the local identity.

Almeida (2016) affirms that music as a method (or possible path) in history teaching can bring great contributions for which, making history classes more attractive, facilitating the teacher, as well as improving student learning, this is one of the new methods that are close to the student's daily life.

Therefore, it is interesting that there are more places to promote Amazonian music, as we highlighted on the radios, schools in their history classes, among others, would be a great way to spread culture as well as increase the appreciation of local identity. 


\section{REFERENCES}

Alves, R. C. (2011). Música Patrimônio Imaterial do Brasil. Revista Lusifonia. Recuperado de https:// revistalusofonia.wordpress.com/2011/02/16/musicapatrimonio- imaterial-do-brasil/

Brasil. (2019). A MPA virou patrimônio cultural de natureza imaterial pela Assembleia Legislativa do Amazonas. Autoria Alessandra Campêlo PL n³95/2019.

Cabocriolo, M. (2021). Depoimentos / Entrevistado por Leonardo Vandersson Pereira Gama. Entrevista concedida ao Projeto de Pesquisa: A influência da música manauara na identidade cultural dos moradores: Um estudo sobre o evento Tacaca na Bossa.

Cileno, M. (2021). Depoimentos / Entrevistado por Leonardo Vandersson Pereira Gama. Entrevista concedida ao Projeto de Pesquisa: A influência da música manauara na identidade cultural dos moradores: Um estudo sobre o evento Tacaca na Bossa.

Costa, M. L., \& Castro, R. V. A. (2008). Patrimônio Imaterial Nacional: preservando memórias ou reconstruindo histórias? Estudos de psicologia. V.13. Recuperado de https://www.scielo.br/pdf/epsic/v13n2/04.pdf

Escobar, D (2021) Depoimentos / Entrevistado por Leonardo Vandersson Pereira Gama. Entrevista concedida ao Projeto de Pesquisa: A influência da música manauara na identidade cultural dos moradores: Um estudo sobre o evento Tacaca na Bossa.

Gil, A. C. (2006). Como elaborar projetos de pesquisa. $4^{a}$.ed. São Paulo: Atlas.

Goldemberg, M. (1999). A arte de pesquisar. 3. Ed. Rio de Janeiro: Record.

Instituto do Patrimônio Histórico e Artístico Nacional. (2003). Convenção para salvaguarda do patrimônio cultural imaterial. Recuperado de https:// ich.unesco.org/doc/src/00009-PT-Brazil-PDF.pdf /

Instituto do Patrimônio Histórico e Artístico Nacional. (2012). Patrimônio cultural imaterial: para saber mais; texto e revisão de Natália Guerra Brayner - 3 ed. Brasília, DF

Instituto do Patrimônio Histórico e Artístico. (2006). Patrimônio Imaterial: O Registro do Patrimônio Imaterial. Dossiê final das atividades da Comissão e do Grupo de Trabalho Patrimônio Imaterial. Recuperado de http://portal.iphan.gov.br/uploads/publicacao/ PatImaDiv_ORegistroPatrimoniolmaterial_1E cao m.pdf

Menezes, M. A. D. (2011). "Eu canto pra falar do Amazonas": narrativas musicais de uma geração de músicos de Manaus. Dissertação (Mestrado em Sociedade e Cultura no Amazonas). Universidade Federal do Amazonas. Manaus, AM: UFAM. Recuperado de https:// tede.ufam.edu.br/bitstream/tede/2342/1/Disserta\% C3\%A7\%C3\%A30\%20-\%20Mauro\%20Augusto\% 20Dourado\%20Menezes.pdf

Novo, M. (2021). Depoimentos / Entrevistado por Leonardo Vandersson Pereira Gama. Entrevista concedida ao Projeto de Pesquisa: A influência da música manauara na identidade cultural dos moradores: Um estudo sobre o evento Tacaca na Bossa.
Pereira, E. S. (2012). Patrimônio Cultural: Uma Reflexão sobre o registro do bem cultural como forma de preservação. Trabalho de Conclusão de Curso (Pós Graduação em Gestão de Projetos Culturais e Organização de Eventos). CELACC/ECA-USP. Recuperado de http:// celacc.eca.usp.br/site/default/files/media/tcc/4481262-1-PB.pdf

Sociedade Artística Brasileira. (2018). Patrimônio Cultural e Música. Recuperado de https://www.sabra.org.br/site/ patrimonio-cultural-e-musica/. Zaoual, H. Nova economia das iniciativas locais: uma introdução ao pensamento pós-global. Tradução de Michel Thiollent. Rio de Janeiro DP\&A: Consulado Geral da França: COPE/UFRJ, 2006. 